\title{
Factors of national regulation of migration processes efficiency: the case study of people's Republic of China
}

\author{
Preecha Phongpheng, ${ }^{1, *}$ \\ ${ }^{1}$ The Office of General Education and Innovative Electronic Learning, Suan Sunandha Rajabhat \\ University, 10200, Dusit, Bangkok, Thailand
}

\begin{abstract}
Since the times when China has started to implement economic reforms, regulation of national migration, especially in the direction from rural areas to large cities, has become one of the core issues in modernization of the whole system of its public management. Consequently, this issue has also become interesting for economic and sociological research. This article studies today's peculiarities of internal labor migration in China and analyzes historic and contemporary forms of the migration policy implementation in this country. The author also discusses the major preconditions for its efficiency as well as opportunities for using certain instruments of Chinese migration policy in modernization of Thailand migration policy, taking into account contemporary economic, social and political challenges.
\end{abstract}

\section{Introduction}

Studies on internal labor migration have become popular and even already traditional during the last couple decades. Seminal studies by John Harris and Michael Todaro have determined the formation of a two-sector model which describes how internal labor migration depends on the differences in wages between rural and urban areas [1]. This theoretical approach of Harris \& Todaro has been later proved numerous times in the course of empirical studies, observations and experiments [2] carried out in many countries, including China.

We also should note here that one of the key peculiarities in the processes of internal labor migration in PRC is the so-called hukou system which has been functioning in the country for over 60 years by now. This system covers a set of rules and principles which together regulate how Chinese people are migrating from rural territories to large cities. Hukou system was officially introduced by Chinese authorities back in the 1960s, and initially it was not aimed on regulation of migration but rather on prevention measures which were supposed to "tie" peasants to the land despite all the opportunities created by quickly developing industrialization and urbanization.

China was in need of cheap agricultural products (and in huge quantities). Thus, massive outflow of rural dwellers to large cities was strongly undesirable, and the

* Corresponding author: preecha.ph@ssru.ac.th 
government understood that very well. The hukou principle has thus strengthened the widening segregation between rural and urban population in China [3].

One of the key principles regulating and limiting internal labor migration was defined (by Chinese authorities) as "communization of private life" for peasants which meant active engagement in various types of communal works. Individual dependence of peasants on their commune was so strong (up to the level of food distribution inside commune) that it was limiting the intention to change the place of residence, even temporary [4].

Once economic reforms were started in the country (1978), the socioeconomic role of a family/household quickly became much more meaningful, while regulative competences of the communes became much weaker, even in the most inner lands. This, naturally, has caused quite active growth of rural population mobility.

On the other side, labor migration from rural areas to cities has stimulated the growth of demand for labor force due to active creation and development of special economic zones and rapid growth of industrial productions in large cities overall. Simultaneous growth of labor force supply in villages and demand growth in cities became rather threatening in terms of uncontrolled migration with all its numerous negative consequences for socioeconomic development of China. And this became the key reason why hukou system has been reformed, first in several provinces only, and then - at the national level overall.

\section{Literature review}

According to the research by P. Huang and F. Pieke [5], the whole history of Chinese migration regulation development can be divided into 4 periods.

Initially (1979 to 1983), Chinese government was still trying to block internal labor migration from villages to cities. Later on (1984 to 1988) authorities allowed peasants relocate to cities but only on a condition he/she will be fully supplied by food products (by other members of the household remaining in rural areas).

Despite such serious limitations, the rates of internal labor migration were still rather high. Thus, in 1995 already many Chinese cities were facing numerous problems with unemployment, criminality and overpopulation. This became the key reason for another tougher stance in national migration policy of China 1995 to 2002.

New millennium with its advanced financial and industrial capacities has forced Chinese authorities turn to regulating internal migration flows in a more targeted way within the most underdeveloped and poor provinces (on the West and North of the country), thus shaping their urban and industrial infrastructure.

Another important feature of Chinese migration policy in the new millennium (since 2000) has been modernization of legal support for internal labor migration. Administrations of small towns have been most active in this field of migration policy improvement. This is quite understandable since towns of smaller size have been actively trying to fight the negative consequences from internal migration.

Prior to 1979, internal labor migration in China was under extremely strict state regulation and control. State authorities were responsible for organizing planned migration of rural population to rapidly developing industrial centers. However, since 1979 rural population started to reveal own interest in such migration, primarily due to significant differences in income levels and life quality between large cities and the rest of China.

As of today there is no exact statistical data on the real sizes and rates of internal labor migration in PRC. Actually, there is no common vision on such migration in the country either. For example, Cai, Du and Wang [6] state that internal migration in China has been actually on the fall - from $35 \mathrm{mln}$ back in 1990 to $14 \mathrm{mln}$ people as of 2009.

On the other side, numerous studies confirm exactly the opposite. For example, West and Zhao [7] provided the statistical evidence to prove that the rates of internal labor 
migration doubled in the period from 1989 till 2008 - from $9 \mathrm{mln}$ up to $25 \mathrm{mln}$ people. Lin, Cai and $\mathrm{Li}[8]$ are of the opinion that internal labor migration is somewhere in the range from 55 to $100 \mathrm{mln}$ people per year. Finally, Huang and Pieke [5] came up with $45 \mathrm{mln}$ internal migrants back in 1990 and then 70 mln migrants as of 2012.

Analyzing the official statistics of PRC (1980 to 2018), provided by the National Bureau of Statistics of China, we should note the following regularities in the development of rural and urban population in the country.

In absolute terms, the rural population in China was steadily growing until 1996. In the period from 1980 till 1996 it grew by around $65 \mathrm{mln}$ people, thus reaching the level of 860 mln people in total. However, since 1996 and on, the volume of rural population started to fall, and drastically (on average, by $8-11$ mln people per year). In 2003 the population number was at the level of the year 1978, and in 2017 it went down to the level of $690 \mathrm{mln}$ people, which is $106 \mathrm{mln}$ less than back in 1979 !

At the same time, the share of rural population in the overall population volume was going down all the time, actually. The relative share of rural population in PRC has been reducing annually by at least $1.5-2 \%$. Thus, in 33 years of official observations it went down from $82 \%$ to $56 \%$ only.

Another interesting fact which indirectly shows how complex is the phenomenon of internal labor migration in China: despite the fact that the rural population in the country was reducing all the time (since 1996), the number of employable rural dwellers was constantly growing!

Thus, back in 1979 the volume of employable rural population was $306 \mathrm{mln}$ people; in 1996 their number was $450 \mathrm{mln}$ already, and in 2004 - over $500 \mathrm{mln}$ people! This trend belongs to the consequences of Chinese birth control policy which was acting for over 30 years: since the number of children in the country was radically reduced, the share of employable population was quickly going up. The number of employable population in rural areas was growing as was growing the generation of those born before 1979.

For obvious reasons, in the near future already the number of employable peasants in China will be quickly falling due to population aging. Thus, despite the truly enormous volume of Chinese population, the country will be soon experiencing lack of labor force!

\section{Results of the study}

According to the official PRC statistics, the number of rural dwellers employed at enterprises in large cities or by urban entrepreneurs is also growing quite dynamically: from $29 \mathrm{mln}$ people back in 1979 to $130 \mathrm{mln}$ in 2001, and then to $152 \mathrm{mln}$ people in 2018.

According to the estimates $75 \%$ of all internal migrants are heading to Eastern provinces on the coast, $15.3 \%$ of migrants go to Western provinces, and only $9.8 \%$ get employed in the central part of the country.

Generally speaking, internal labor migrants in China tend to be younger and better educated than those rural dwellers that prefer to stay at home. This trend can be explained by the traditional role of women in villages and also by much higher demand for male labor on the side of construction companies and huge industrial enterprises located in Eastern provinces.

Most of migrants from rural areas leave their home very early, 24\% of all rural migrants are younger than 19 y.o.; migrants from small towns tend to be slightly older $(26 \%$ of migrants from towns are between 21 and 26 years old).

Migrants from towns are usually better educated, $35 \%$ of them have college education. But their work far from home turns out to be most short-term: $60 \%$ of all labor migrants spend no more than 6 months in the industrial megapolises on the East coast; $44 \%$ of internal migrants start for over a year. 
$36 \%$ of the labor migrants work at industrial enterprises; $20 \%$ get employed on construction sites, and only $8 \%$ are working in services.

Since hukou system is still working in China, it would be very hard for internal labor migrants to get officially employed in a new place. Thus, the share of illegal/shadow employment in the country is still quite high. According to some estimations, it is currently at the level of about $35 \%$.

Table 1. Socioeconomic conditions of internal labor migrants' life in China as compared to local workers (Calculated by the author, data for 2018).

\begin{tabular}{|l|c|c|c|c|c|}
\hline \multirow{2}{*}{} & $\begin{array}{c}\text { Local } \\
\text { workers }\end{array}$ & Migrants & \multicolumn{2}{|c|}{$\begin{array}{c}\text { Local } \\
\text { workers }\end{array}$} & Migrants \\
\cline { 2 - 5 } & \multicolumn{2}{|c|}{ Legal sector } & \multicolumn{2}{|c|}{ Illegal sector } \\
\hline Working hours perk & 5.3 & 6.0 & 6.0 & 6.8 \\
\hline Working hours in a day & 8.2 & 8.7 & 8.9 & 10.6 \\
\hline Monthly salary in yuans & 1387 & 1247 & 1094 & 976 \\
\hline $\begin{array}{l}\text { The share of workers who have pension } \\
\text { savings, in \% }\end{array}$ & 82.1 & 29 & 55 & 2.1 \\
\hline $\begin{array}{l}\text { The share of workers with unemployment } \\
\text { insurance, in \% }\end{array}$ & 39.7 & 17.8 & 12.6 & 0.4 \\
\hline $\begin{array}{l}\text { The share of workers with work safety } \\
\text { insurance, in \% }\end{array}$ & 29 & 31.7 & 6.0 & 1.2 \\
\hline $\begin{array}{l}\text { The share of workers with medical insurance, } \\
\text { in \% }\end{array}$ & 71.4 & 29.7 & 32.6 & 1.3 \\
\hline
\end{tabular}

Table 2. Average differences in wages between local residents and labor migrants, by economic sectors (Calculated by the author, data for 2018).

\begin{tabular}{|l|c|}
\hline \multicolumn{1}{|c|}{ Industries } & Average difference in wages, in \% \\
\hline Services & 16 \\
\hline Hospitality & 14 \\
\hline Retail sector & 13.5 \\
\hline Transportation \& logistics & 15 \\
\hline Construction & 33 \\
\hline Production & 12 \\
\hline
\end{tabular}

Table 3. Living conditions of labor migrants in China, \% (Calculated by the author, data for 2018).

\begin{tabular}{|l|c|}
\hline \multicolumn{1}{|c|}{ Living conditions of labor migrants } & $\%$ \\
\hline more comfortable conditions & 11 \\
\hline a place with amenities and a kitchen & 21 \\
\hline a place with amenities & 22.9 \\
\hline dormitory & 31 \\
\hline barracks & 6.4 \\
\hline directly on a workplace & 7.8 \\
\hline
\end{tabular}

\section{Discussion}

Taking into account the current demographic and economic conditions in PRC, Chinese migration policy clearly needs some change in its priorities: the strategy of limiting quantitative growth in labor supply should be substituted by a strategy concentrated on the 
qualitative factors of development. As the country's today's statistics demonstrates, China cannot be called a state with limited labor reserves (especially in relation to agriculture). Huge volumes of labor resources make the problem of efficient engagement of national labor force especially acute, especially taking the issue of population aging in its middle and long term.

Foreign experience knows only one pattern for radical change of the migration paradigm: rapid growth of labor productivity, primarily, by means of raising the qualification level of the labor resources and high human potential of the country overall. Only such radical measures could help with solving the problem of physical labor appreciation in the country (due to lowering number of young people) and also the problem of growing economic costs due to population aging (as older people are often not really capable of hard physical labor).

Despite all the successes already achieved, the current structure of Chinese society is shaped so that the share of youth ready to learn is not that numerous (this is the result of the long-term policy of birth limitations). At the same time, the aging part of the population is not really capable of either learning (even if this means continuing own career path in the industrial sector of services), or returning to agricultural work back in the village.

In the coming 10-20 years already China will face an acute social problem of serious economic differentiation [9]. Adult generation will be substituted (partially due to growing automation of many productions and also due to inflow of younger professionals), and this will mean more unemployment in the country. Considering that there is no pension system in PRC as such and also the growing consequences from the long-term demographic policy "one family - one baby", the representatives of the older generation have all the chances to form a social class of new Chinese poor! Previously, most of poor people in China were of rural origin, but this newer class would be "urban poor people". Once again, these people won't be able to return to the traditional farming life already (due to age, difficulties with switching from the urban life style and so on). The forecasted volume of these potentially poor people is really enormous - larger than the whole population of the European Union!

Chinese authorities are well aware of these demographic threats of the coming two decades. That's why today already they are starting to invest more in training and retraining of adult population $(40+)$ rather than investing in education of rural youth. Today already the system of auxiliary education in China plays the role equal to that of traditional education institutions. And the first successful results are already visible.

Thus, if in 2004 the share of people with university education among adult migrants was only $24 \%$, in 2016 already their share went beyond $36 \%$ [10].

\section{Conclusions}

Apart from these prevention measures aimed at overcoming the negative consequences of demographic development, Chinese experience can be also useful (for Thailand, but not only) in part of development and implementation of the migration policy.

Efficiency of Chinese migration policy is, first of all, achieved thanks to its flexible reaction to changing business demands [11]. Chinese authorities initially used to be rather harsh in what concerns regulation of internal migration (up to the level of complete prohibition of labor migration as such). Later on, the authorities started following business demands as they were interested in creating most comfortable conditions for business development. Thus, some of the limitations and prohibitions were removed with the aim to regulate and direct the flow of internal labor migration. We also need to mention here that this strict system of prohibitions and limitations concerned solely internal migration, while Chinese emigration (especially temporary one) as well as repatriation of ethnical Chinese were enjoying the most liberal conditions $[12,13]$. 
Moreover, Chinese authorities, for some time, were actively welcoming the outflow of talented Chinese youth for further studies abroad and temporary employment, especially if that concerned working for the most innovative corporations of the US, Europe, Canada and Australia. However, all that assumed that at some point young Chinese migrant was expected to return and continue working for the motherland already. Such policy measures cover a wide range of state grants, scholarships, student exchange programs and other forms of international cooperation between universities.

Also, we can note that Chinese migration policy tends to be of a rather sectoral nature. The whole internal labor migration is actually limited to about a dozen sectors, the ones with the largest demand in physical labor. Such sectoral targeting of the national migration policy can be helpful for many other countries, including Thailand, as it has several explicit benefits.

First, it fuels businesses' interest in raising labor productivity by means of using advanced technologies and other innovations (in case of unregulated migration such business motivation quickly disappears, as it is the case in Thailand).

Secondly, targeted migration policy motivates the population to get better education since the latter guarantees better jobs without the necessity to leave the region of origin.

Thirdly, internal labor migration and its volumes in the first place remain to be rather strictly regulated till now, and most probably, this is really necessary for a country with such huge population numbers.

Finally, also useful can be Chinese experience in reclamation of underdeveloped Western territories of the country which was directly tied with the national migration policy.

\section{References}

1. J. Harris, M. Todaro, American Economic Review 1, 126 (1970).

2. D. Wang, Y. Wu, F. Cai Migration, unemployment, and urban labor market segregation in China's economic transition (Beijing: Institute of Population and Labor Economics, Chinese Academy of Social Sciences, 2003).

3. F. Cai, Y. Du, J. of Economic Research 10, 119 (2010).

4. Y. Zhao, American J. of Agricultural Economics 1, 1278 (1997).

5. P. Huang, F. Pieke, Regional Conference on Migration, Development and Pro-Poor Policy Choices in Asia (Dhaka, 2013).

6. F. Cai, Y. Du, M. Dang, How Far is China to A Labor Market. (Beijing, China Commerce Press, 2010).

7. A. West, Y. Zhao, Rural Labor Flows in China. Berkeley (Institute of East Asian Studies, University of California, 2009).

8. J. Lin, F. Cai, Z. Li, The China Miracle: development Strategy and Economic Reform (Hong Kong, Chinese University Press, 2016).

9. D. Ushakov, P. Vivatpattanakul, EUrASEANs 2(3), 60 (2017).

10. J. Taylor, S. Rozelle, A. de Brauw, Economic Development and Cultural Change 52(1), 75 (2017).

11. F. Cai, Y. Du, M. Wang. The Political Economy of Labor Migration (Shanghai, Shanghai Sanlian Bookstore, Shanghai People's Press, 2013).

12. O. Lokota, E. Kozlova, EUrASEANs 4(5), 7 (2017).

13. N. Zhu, China Economic Review 2-3, 213 (2002). 